IFN Working Paper No. 904, 2012

\title{
The International Mobility of the Super-Rich
}

\section{Tino Sanandaji}




\title{
The International Mobility of the Super-Rich*
}

\author{
Tino Sanandaji ${ }^{\dagger}$
}

14 Ferburary 2012

\begin{abstract}
Relying on Forbes Magazine annual rankings for two decades, 1625 billionaires and their countries of birth and residence are identified, most of whom are self-made entrepreneurs. 13 percent of billionaires reside in a country other than that of their birth. Migration is linked to distance, to cultural ties and to the per capita income of the respective source and host country. Capital taxes have a statistically significant though economically modest effect. 80 percent of those who moved migrated from a lower per capita income to a higher per capita income country and 70 percent from a higher tax country to a lower tax country. Self-made billionaires are more likely to move to countries with larger market sizes.

Overall surprisingly few billionaire entrepreneurs migrate. Previous research has found that self-employed tend to work in their home community at higher rates than employees. Entrepreneurship too appears to be local, with private equity be characterized by a home bias. One explanation may be the wide dispersion and local nature of information as emphasized by Hayek.
\end{abstract}

JEL codes. L26, F22, H2

Keywords: Entrepreneurship; Migration; Taxes.

*Financial support from the Jan Wallander and Tom Hedelius Research Foundation is gratefully acknowledged. I thank David Cesarini, Kerwin Charles, Robert Lalonde and Raaj Sah for useful comments and suggestions.

${ }^{\dagger}$ Harris School of Public Policy, University of Chicago, 1155 East 60th Street, Chicago, IL 60637, and the Research Institute of Industrial Economics, Stockholm, Sweden. 


\section{Introduction}

Scarcely any group is less representative of the population as a whole than billionaires. But what the world's richest lack in representativeness, they make up in economic importance. The net worth of American billionaires alone is one and a half trillion dollars, or three percent of national wealth. Moreover, the popular interest in the super-rich has motivated careful collection of data on them. Forbes Magazine's list of the world's billionaires is constructed by 40 journalists, and includes information on the country of residence and citizenship, and on the source and amount of wealth. In this paper, after adding some additional data, this information is utilized to investigate the international mobility of 1625 super-rich individuals across 153 potential countries. One advantage of this dataset is that unlike micro-datasets within each nation it tracks individuals across international borders, which allows both push and pull effects to be studied simultaneously.

\section{Previous research}

Hunter et al. (2009) investigate the mobility of top researchers, finding that countries with high R\&D expenditure attract scientists. Michelacci and Silva (2007) documented a tendency for the self-employed to be unusually "local", that is to say, less likely to move within countries than workers. There is however comparatively little research on the mobility of high-impact entrepreneurs. Borjas and Bratsberg (1996) show that overall distance and per capita GDP influences the migration decision.

The responsiveness of the rich to taxes has been empirically studied across several margins (e.g Alm and Wallace, 2000, Goolsbee, 2000, Gruber and Saez, 2002). The possibility that the rich migrate lower their capital tax burden has however not been investigated. Kleven et al. (2011) studies the mobility of soccer players in Europe in response to changes in tax rates, finding that taxes influence migration.

One problem in linking taxes to migration is that micro-datasets require the individual to be present in the dataset in all periods, typically excluding new entrants and those who emigrate and exit the sample. Bakija and Slemrod (2004) find that state inheritance and estate taxes have a detectable but modest effect on the migration of the rich within the U.S. Studies on tax 
induced inter-region migration in Canada (Day and Winer, 2006) and Switzerland (Leibig and Sousa-Poza, 2006) have found no evidence that taxes influence the decision to relocate. Coomes and Hoyt (2008) investigated the location choices of individuals who moved into "multi-state" cities - city areas that encompass more than one state and tax regime, finding small effects.

\section{Construction of Empirical Measure.}

All individuals who appeared at least once on the Forbes Magazine international list of billionaires between 1996 and 2010, and for whom data on country of birth could be found, are included. The last year they appear on the list is used to determine the amount of wealth and country of residence. A three step process was used to determine the country of birth. Forbes provides a brief biographical note for most billionaires, which was naturally used as the first source of data. Second, for most billionaires, Wikipedia provides data on country of birth. If neither of these sources were sufficient to determine the country of birth a Google search was undertaken. Ultimately the country of birth was determined for 1625 of the 1723 billionaire's in the dataset.

Per capita income and population figures are from the IMF database. Information on borders, distance between the largest cities, language ties and colonial links were gathered from the Geodistance database, CEPII (2010). Data on the top marginal capital gains tax is collected from ASI (2010), American council for capital formation (2008), The World Bank database and the Deloitte International Tax Source database. Reliable data on all these measures were found for 153 countries, which comprise more than 95 percent of the world's population. Countries which saw no immigration of billionaires are also included, since they are potential destinations of immigration.

Forbes Magazine divides billionaires into two groups, those who inherited their wealth and those who earned their wealth, and are classified as "self-made". Self-Made billionaires constitute 65 percent of the sample. Sanandaji (2010) shows that more than nine out of ten self-made billionaires in this sample are entrepreneurs who founded new firms. There is a theoretical expectation that the size of the market matters for the return to top talent (Murphy et al. 1991). For this reason an interaction variable will be created for self-made source of wealth and 
the size of the destination market. Any billionare migrating during their lifetime, thusfar, is identified, which is an advantage when accounting for lags. The disadvantage is that we cannot tell us if the billionaire moved before or after becoming wealthy, which is a concern for the self-made billionaires. In some cases the mobility represents immigrants who became rich after moving to a new country, and in some cases it represents the relocation of the already rich. In this paper both types are treated identically.

\section{Results}

Of the 1625 billionaires, 13 percent reside in another country than that which they were born in. As a comparison, 10 percent of the population of developed nations are thought to be immigrants (UN 2006). In the United States, 16 percent of the workforce is foreign born, while 12 percent of self-made billionaires are foreign born. Among self-made billionaires in the United States who are entrepreneurs, a similar 11 percent are foreign born (Sanandaji 2010).

While global talent is evenly distributed across countries, economic opportunity remains concentrated in a number of wealthy countries. As a comparison, one half of the world's mostcited physicists work outside their country of birth (Hunter et al. 2009). We might therefore also expect a high percentage of the self-made rich to be foreign born. Anecdotally, immigrant entrepreneurs played an important role in places such as Silicon Valley, helping found firms such as Google and eBay. In light of this, the modest share of self-made billionaires (more than ninety percent of which are entrepreneurs) who are foreign born may appear surprising. This is however consistent with previous research, which finds that the foreign born are slightly underrepresented as high-impact entrepreneurs compared to their share of the labour force (Hart and Asc, 2011).

The results are most readily explained with refrence to the finding in Michelacci and Silva (2007) that the self-employed are "local", that is to say less likely to move within countries. A plausible explanation is that information is widely disperses within society and local in nature (Hayek, 1945). Similarly, a consistent "home-bias" has been detected regarding financial investments (French and Poterba, 1991). Considering the strong preference of stockowners to invest in their home country and the even higher transaction and information costs associated with private equity investments, it is understandable that entrepreneurs prefer to do business in the 
market they know best. Bussinessmen appear to have country-specific knowledge and skills.

Of the billionaires that migrated, 80 percent moved from a lower per capita GDP country to a higher per capita GDP country and 70 percent from higher to lower capital gains tax country. Approximately 60 billionaires migrated to and 13 out of the United States, the world's largest attractor of the rich. The size of the fortune of billionaires does not appear to systematically influence the choice of migration. One third of the billionaires that moved went to small countries defined as "tax heavens" by Hines (2010). This includes Switzerland (to which 23 billionaires emigrated), Hong Kong (20), Monaco (8), Singapore (6), Bermuda (4), Gibraltar (3), Bahamas (2), Costa Rica (1), Cyprus (1), Barbados (1) and The Cayman Islands (1). Billionaires from high tax Nordic countries such as Sweden appear particularly likely to migrate

Since the rich can and often do move to and from the same countries, a dyadic setup will be relied on where each country is in turn both the potential origin of and destination for the migrants. This approach has been used to among others analyze trade flows (e.g Morrow et al. 1998) and the policy diffusion process (Gilardi, 2010). The main drawback of this approach is the likely existence of omitted variables. Tax rates may for example be correlated with other factors that influence mobility, which would then bias the estimates ${ }^{1}$. The regressions reported in Table 1 confirm that billionaires move from poorer to richer countries, as both the wealth of the home country and destination country are linked with the likelihood of migration. Capital gains taxes in the destination country appear to have a small but detectable impact on the probability of migration, though no effect is found from the capital gains tax in the home country. As expected distance reduces the likelihood of migration. Cultural ties such as a common language and colonial ties increase the likelihood of migration. So for example many German-born billionaires live Switzerland, while many Indian-born billionaires moved to the U.K, Canada and the United States. The aggregate size of the destination country market increases the probability of migration, and more so for self-made billionaires. This is suggestive evidence in support of Murphy et al. (1991), who argue that top talent seeks out the largest market.

\footnotetext{
${ }^{1}$ Another concern is that we rely on the statutory rather than effective gains tax rates. Measurement error in the explanatory variable of this form may lead to attenuation in the estimated coefficients, making taxes appear less important than they are.
} 
Table 1. Determinants of the International Mobility of the Ultra-Wealthy.

\begin{tabular}{|c|c|c|c|c|}
\hline & (1) & (2) & (3) & $(4)$ \\
\hline Home GDP & $\begin{array}{c}-0.015^{* *} \\
(0.006)\end{array}$ & $\begin{array}{c}-0.014^{* *} \\
(0.006)\end{array}$ & $\begin{array}{c}-0.014^{* *} \\
(0.006)\end{array}$ & \\
\hline Destination GDP & $\begin{array}{c}0.032^{* * *} \\
(0.003)\end{array}$ & $\begin{array}{c}0.032^{* * *} \\
(0.003)\end{array}$ & $\begin{array}{c}0.035^{* * *} \\
(0.002)\end{array}$ & \\
\hline Home Tax & $\begin{array}{c}-0.017 \\
(0.7091)\end{array}$ & $\begin{array}{c}0.008 \\
(0.7139)\end{array}$ & & $\begin{array}{c}-0.081 \\
(0.6748)\end{array}$ \\
\hline Destination Tax & $\begin{array}{c}-1.811^{* * *} \\
(0.697)\end{array}$ & $\begin{array}{c}-1.773^{* *} \\
(0.697)\end{array}$ & & $\begin{array}{c}-2.326^{* * *} \\
(0.405)\end{array}$ \\
\hline Destination Market Size & $\begin{array}{c}0.247^{* * * *} \\
(0.028)\end{array}$ & & & \\
\hline Selfmade & $\begin{array}{l}-0.283 \\
(0.198)\end{array}$ & & & \\
\hline Interaction & $\begin{array}{c}0.062^{* *} \\
(0.031)\end{array}$ & & & \\
\hline Distance & $\begin{array}{c}-0.091^{* *} \\
(0.027)\end{array}$ & $\begin{array}{c}-0.089^{* * *} \\
(0.027)\end{array}$ & $\begin{array}{c}-0.089^{* * *} \\
(0.027)\end{array}$ & $\begin{array}{c}-0.056 \text { *** } \\
(0.021)\end{array}$ \\
\hline Common Language & $\begin{array}{c}1.427^{* * *} \\
(0.169)\end{array}$ & $\begin{array}{c}1.456^{* * * *} \\
(0.166)\end{array}$ & $\begin{array}{c}1.513^{* * * *} \\
(0.163)\end{array}$ & $\begin{array}{c}1.519^{* * *} \\
(0.143)\end{array}$ \\
\hline Colony & $\begin{array}{c}0.736^{* * *} \\
(0.282)\end{array}$ & $\begin{array}{c}0.686^{* *} \\
(0.277)\end{array}$ & $\begin{array}{c}0.638^{* *} \\
(0.273)\end{array}$ & $\begin{array}{c}0.504^{* *} \\
(0.240)\end{array}$ \\
\hline Constant & $\begin{array}{c}-5.515^{* * *} \\
(0.350)\end{array}$ & $\begin{array}{c}-5.772^{* * *} \\
(0.303)\end{array}$ & $\begin{array}{c}-6.077^{* * *} \\
(0.251)\end{array}$ & $\begin{array}{c}-4.908^{* * *} \\
(0.209)\end{array}$ \\
\hline $\begin{array}{l}\text { Pseudo } R^{2} \\
\# \text { Obs }\end{array}$ & $\begin{array}{l}0.289 \\
32528\end{array}$ & $\begin{array}{l}0.287 \\
32528\end{array}$ & $\begin{array}{l}0.285 \\
32528\end{array}$ & $\begin{array}{c}0.099 \\
32528\end{array}$ \\
\hline
\end{tabular}

Results are from a logistic regression where the dependent variable represents moving from the home country to the potential destination country, with errors clustered on individual and country. "Home GDP" and "Destination GDP" refer to the PPP-adjusted GDP of the country of birth and potential destination country in 2009 from the IMF. "Home Tax" and "Destination Tax" refer to the capital gains tax rate. "Destination Market Size" is the per capita GDP of the potential destination country multiplied by its population. "Selfmade" is a dummy equal to one if Forbes Magazine classifies the billionaire as self-made. Interaction is an interaction variable of "Selfmade" and "Destination Market Sizet". "Distance" measures bilateral distance between country capitals in kilometers. "Common language" is a dummy variable equal to one if home and potential destination countries 
speak the same language. "Colony" is a dummy variable equal to one if home and potential destination countries colonized each other. "Contingent" is a dummy variable signifying a common border. Three stars $(* * *)$ denote statistical significance at the $1 \%$ level and two stars $(* *)$ denote statistical significance at the $5 \%$ level.

\section{Conclusion}

The international mobility of the world's richest individuals is investigated. Billionaires are more likely to move to geographically proximate countries with cultural and political ties, and more likely to move from poorer to richer nations.

Capital gains taxes in the potential destination country appear to have a statistically detectable but economically minor impact on the location decision of the rich. Taxes matter, but do not appear to be a major determinant of the international migration of the super-wealthy, simply since most billionare's never move.

Given the upward potental, surprisingly few self-made billionaires - almost all of whom are entrepreneurs - migrate between countries. In the United States, immigrants are slightly underrepresented as billionaire entrepreneurs, countrary to popular impression. There thus appears to be a home-bias in private equity, similar to the home bias in public equity and the documented tendency for the self-employed to remain close to their hometowns in their bussiness activity. A potential explanation for this phenomenon is the wide dispersion of knowledge in society (Hayek, 1945). Entrepreneurs know their home market best and are most likely to succeed where they have an information advantage.

\section{References}

[1] ACCF (2008), American council for capital formation special report.

[2] Adam Smith Institute (2010), 'The Effect of Capital Gains Tax Rises on Revenues', http://www.adamsmith.org/research/reports/the-effect-of-capital-gains-tax-riseson-revenues.

[3] Alm, James and Sally Wallace (2000), 'Are the Rich Different?', in Slemrod, Joel (ed.). Does Atlas Shrug?: The Economic Consequences of Taxing the Rich, Russell Sage Foundation: New York. 
[4] Bakija, Jon, and Joel Slemrod (2004), 'Do the Rich Flee from High State Taxes? Evidence from Federal Estate Tax Returns', NBER Working Paper No. 10645.

[5] Baumol, William J (2010), The Microtheory of Innovative Entrepreneurship .Princeton University Press: Princeton, New Jersey

[6] Borjas, George and Bratsberg, Bernt (1996), 'Who Leaves? The Outmigration of the Foreign-Born', The Review of Economics and Statistics, 78, 165-76.

[7] CEPII (2010), CEPII Geodesic distances, www.cepii.fr.

[8] Coomes, Paul, and William H. Hoyt. (2008), 'Income taxes and the destination of movers to multistate MSAs', Journal of Urban Economics, 63, 920-937.

[9] Day, Kathleen, and Stanley Winer. (2006), 'Policy-Induced Internal Migration: An Empirical Investigation of the Canadian Case' International Tax and Public Finance, 13, 535-564.

[10] Deloitte (2011), Deloitte International Tax Source

[11] French, Kenneth and James Poterba (1991), 'Investor Diversification and International Equity Markets', American Economic Review, 81, 222-226.

[12] Gilardi, Fabrizio (2010), 'Who Learns from What in Policy Diffusion Processes?' American Journal of Political Science, 54, 650-666.

[13] Goolsbee, Austan (2000), 'What Happens When You Tax the Rich? Evidence from Executive Compensation', Journal of Political Economy, 108, 352-78.

[14] Gruber, Jon, and Emmanuel Saez. (2002), 'The Elasticity of Taxable Income: Evidence and Implications', Journal of Public Economics, 84, 1-32.

[15] Hart, David and Zoltan Acs (2011), 'High-Tech Immigrant Entrepreneurship in the United States', Economic Development Quarterly, 25, 116-129.

[16] Hayek, Fredrich. A. (1945), 'The Use of Knowledge in Society', American Economic Review, 35, 519-530.

[17] Hines, James (2010), 'Treasure Islands' Journal of Economic Perspectives, 24, 103-126. 
[18] Hunter, Rosalind, Andrew Oswald and Bruce Charlton (2009), 'the Elite Brain Drain' The Economic Journal, 119, 231-251.

[19] Liebig, Thomas and Alfenso Sousa-Poza (2006), 'The influence of taxes on migration: evidence from Switzerland', Cambridge Journal of Economics, 30, 235-252.

[20] Michelacci, Claudio and Olmo Silva (2007), 'Why So Many Local Entrepreneurs?', The Review of Economics and Statistics, 89, 615-633.

[21] Morrow, James.,Randolph Siverson, and Tressa Tabares (1998), 'The Political Determinants of International Trade: The Major Powers, 1907-90', American Political Science Review, 92, 649-61.

[22] Murphy, Kevin, Andrei Shleifer and Robert Vishny (1991), 'The Allocation of Talent: Implications for Growth', The Quarterly Journal of Economics, 106, 503-30.

[23] Sanandaji, Tino (2010) 'Self-Employment Does not Measure Entrepreneurship' Working Paper.

[24] Slemrod, Joel. (2000), 'The Economics of Taxing the Rich', in Slemrod, Joel (ed.). Does Atlas Shrug?: The Economic Consequences of Taxing the Rich, Russell Sage Foundation: New York.

[25] United Nations (2006), International Migration Report 2006: A Global Assessment, United Nations. 